\title{
New record of larval Hysterothylacium sp. (Nematoda: Raphidascar- ididae) in pick handle barracuda (Sphyraena jello) from the Persian Gulf, Iran
}

\author{
A Taheri Mirghaed ${ }^{1}$, M Ghadam ${ }^{1}$, H Ebrahimzadeh Mousavi ${ }^{1}$, M Soltani ${ }^{1}$, P Shohreh ${ }^{1}$, H Rahmati Holasoo ${ }^{1}$, I \\ Mobedi $^{2}$ and A Banitalebi ${ }^{3}$ \\ ${ }^{1}$ Department of Aquatic Animal Health, Faculty of Veterinary Medicine, University of Tehran, Tehran, Iran \\ ${ }^{2}$ Department of Parasitology, Faculty of Hygiene, Tehran University of Medical Sciences, Tehran, Iran \\ ${ }^{3}$ Department of Aquatic Animals Health \& Diseases, Hormozgan Veterinary Organization, Bandar Abbas, Iran
}

Recived: September 2015

\begin{abstract}
Pick handle barracuda (Sphyraena jello) is one of the most important commercial species in the Persian Gulf. In order to investigate prevalence and intensity of nematoda, $150 \mathrm{~S}$. jello from three sites (Khuzestan, Bushehr and Hormozgan provinces) of the Iranian coast of the Persian Gulf were monthly investigated in the period 2012-2013. The nematodes belonging to the genus Hysterothylacium (family Raphidascarididae) were isolated from the abdominal cavity and digestive tract with a prevalence of $12 \%$ and mean intensity of 4.8 . Intensity of infestation was increased with size of the host $(\mathrm{P}<0.05)$. This study is the first report of presence of the third and fourth- stage of an unreported type of Hysterothylacium larvae in S. jello from the Persian Gulf.
\end{abstract}

Keywords: Sphyraena jello, Hysterothylacium sp., nematodes, Persian Gulf.

\section{Introduction}

The Persian Gulf has a vast potential of marine fish commercial production. Three coastal provinces of Iran have important fisheries on their side of the Persian Gulf: Khozestan in the northwest, Hormozgan in the northeast and Boushehr in the center of the

Correspondence H Ebrahimzadeh Mousavi, Department of Aquatic Animal Health, Faculty of Veterinary Medicine, University of Tehran, Tehran, Iran (e-mail: hmosavi@ut.ac.ir)
Accepted: December 2015

Persian Gulf. The pickhandle barracuda (Sphyraena jello) is a member of the Sphyraenidae family that includes 21 species. It grows to $150 \mathrm{~cm}$ in length and maximum weight of about $11.5 \mathrm{~kg}$ and feeds mainly on fishes. The mentioned species is widely distributed in marine and brackish water being one of the most commercially important coastal fish in the Persian Gulf (Randall, Allen \& Steene 1997; Hoese, Bray, Paxton \& Allen 2006).

The anisakid nematodes can be transmitted to man, and fish can act as intermediate, paratenic or definitive hosts (Anderson 2000). In humans, the ingestion of their third-stage larvae through consumption of lightly cooked or raw marine fish and invertebrates infested with anisakid larvae can cause anisakiasis (Nagasawa 2005). Hysterothylacium larvae under natural conditions can reach sexual maturity in the digestive tract of bony fish (Køie 1993) or in marine mammals (Deardorff \& Overstreet 1982). Although, they may be less of a hazard for humans compared to other genera, some species have been considered as being of zoonotic interest (Deardorff \& Overstreet 1981b). They have been recorded from several freshwater and marine fish (Deardorff \& Overstreet 1981a,b) or both (Brizzola \& Tanzola 1995), in several parts of the world, Likewise H. punctati was isolated from the freshwater fish spotted snake head, Channa punctata (Lakshmi 1995b), and $\mathrm{H}$. japonicum was reported from the marine fish slender ribbonfish, Trachipterus ishikawae in Japan (Moravec \& Nagasawa 1998). Hysterothylacium sp. was recovered from a cage-cultured coho salmon, Oncorhynchus kisutch in Chile (Carvajal 
\& González 1990). In Brazil, large-tooth flounder, Paralichthys isosceles was recognized as new host for Hysterothylacium larvae (Felizardo, Knoff, Pinto \& Gomes 2009). Several studies on Hysterothylacium sp. have been undertaken from the Persian Gulf (Kardousha 1992; Petter \& Sey, 1997; Al-Behbehani 2003; Bagherpour, Afsharnasab, Mobedi, Jalali \& Mesbah 2011). The present study investigated presence of the third and fourth- stage of an unrecorded type of Hysterothylacium larvae in $S$. jello from the Persian Gulf demonstrating that this fish can act as intermediate or definitive host for this parasite.

No human anisakiasis is yet recorded from Iran but with an increasing trend to use undercooked or raw fish among Iranians, the prevalence of anisakiasis cases is expected to merge. As anisakiasis is considered as an emerging zoonosis, anisakid larvae require more attention of investigation of their morphology, biology and life cycle.

\section{Materials and Methods}

A total number of $150 \mathrm{~S}$. jello were sampled from three sampling sites (Khuzestan, Bushehr and Hormozgan provinces) along the Iranian coast of the Persian Gulf from August 2012 to December 2013. Fish were collected from fish harbors randomly. The specimens were $20-80 \mathrm{~cm}$ in length and 200-1200 g of weight. They were examined for anisakid larvae infection, transported to the Veterinary Organization laboratories and eviscerated. Abdominal cavity was washed under running water into a 50 mesh sieve to remove adhering larvae. Skin, abdominal cavity, stomach, sub- serous tissues, stomach and intestine contents, liver, spleen and gonads were examined macroscopically using a stereomicroscope to isolate anisakid larvae. Larvae (Fig. 1) were counted, fixed in $70 \%$ ethanol, cleared in lactophenol for $48 \mathrm{~h}$ for identification. Schematic drawing was prepared by camera lucida with drawing tube (ZIESS-West Germany). Identification was carried out using available keys (Gibbons 2010). Prevalence and intensity were calculated according to Bush, Lafferty, Lotz \& Shostak (1997) and data analysis of the parasites and hosts were carried out using SPSS, version 16. t-test was used for comparison of the means and to determine the relation between size of fish and parasitic intensity, at significance level of 0.05 . Voucher specimens have been deposited in the Collection of the National Museum of Parasitology, University of Tehran, Tehran, Iran, ID: 763, Hysterothylacium sp.

\section{Results}

Out of 150 investigated fish, in 18 specimens Hysterothylacium sp. Ward \& Magath, 1917 were identified with a prevalence of $12 \%$ and mean intensity of 4.8. Intensity of infestation was increased with the size of the host $(\mathrm{P}<0.05)$. In the present study, identified larvae represented L3 and L4 stages of Hysterothylacium sp. and were removed from the abdominal cavity and digestive tract of S. jello and none of the parasites were found in the liver, spleen and gonad (The measurements are given in Table 1).

\section{Discussion}

\section{Description based on 39third-stage larvae}

They had a dorsal and two ventro-lateral lips and boring tooth was absent (Fig. 2). Excretory pore was at the level of nerve ring. Ventriculus had nearly oval shape, intestinal caecum was extended anteriorly and ventricular appendix was projected posteriorly. Four rectal glands were present. Conical tail was tipped with the arranged spines in a circle (Fig. $3)$.

\section{Description based on 19 fourth-stage larvae}

All of the mentioned characteristics were observed in four-stage larvae, except for the presence of the more developed lips and cactus tail with multi-spinous structure in the posterior end (Fig. 4), its features in having cavernous alaes and extended chords at the cross section approved the results (Fig. 5).

The ascaridoidea naturally parasitize fish, cephalopods, marine mammals and piscivorous birds. Humans can become accidental hosts by ingesting raw marine fish and invertebrates infested with third stage larvae (Doupe', Lymbery, Wong \& Hobbs 2003). The larvae invade the gastrointestinal mucosa and cause abdominal pain, vomiting, nausea, and 
Iranian Journal of Aquatic Animal Health

Table1 Measurements (mm) of Hysterothylacium sp.

\begin{tabular}{llll}
\hline Structures $(\mathrm{mm})$ & Minimum size & Maximum size & Mean \pm SD \\
\hline Body length & 20.5 & 28.8 & $24.5 \pm 2.43$ \\
Body width & 0.9 & 1.3 & $1.1 \pm 0.13$ \\
Esophagus L. & 1.385 & 2.88 & $2.1 \pm 0.44$ \\
Esophagus W. & 0.19 & 0.395 & $0.285 \pm 0.05$ \\
Intestinal Caecum L. & 0.45 & 1.05 & $0.72 \pm 0.19$ \\
Intestinal Caecum W. & 0.15 & 0.32 & $0.23 \pm 0.05$ \\
Ventriculus L. & 0.21 & 0.45 & $0.32 \pm 0.07$ \\
Ventriculus W. & 0.18 & 0.375 & $0.27 \pm 0.05$ \\
Ventricular appendix L. & 2.9 & 5.85 & $4.3 \pm 0.97$ \\
Ventricular appendix W. & 0.165 & 0.375 & $0.275 \pm 0.06$ \\
Spineous end & 0.015 & 0.027 & $0.02 \pm 0.004$ \\
\hline
\end{tabular}

L.- Length, SD.- Standard Deviation, W.- width.

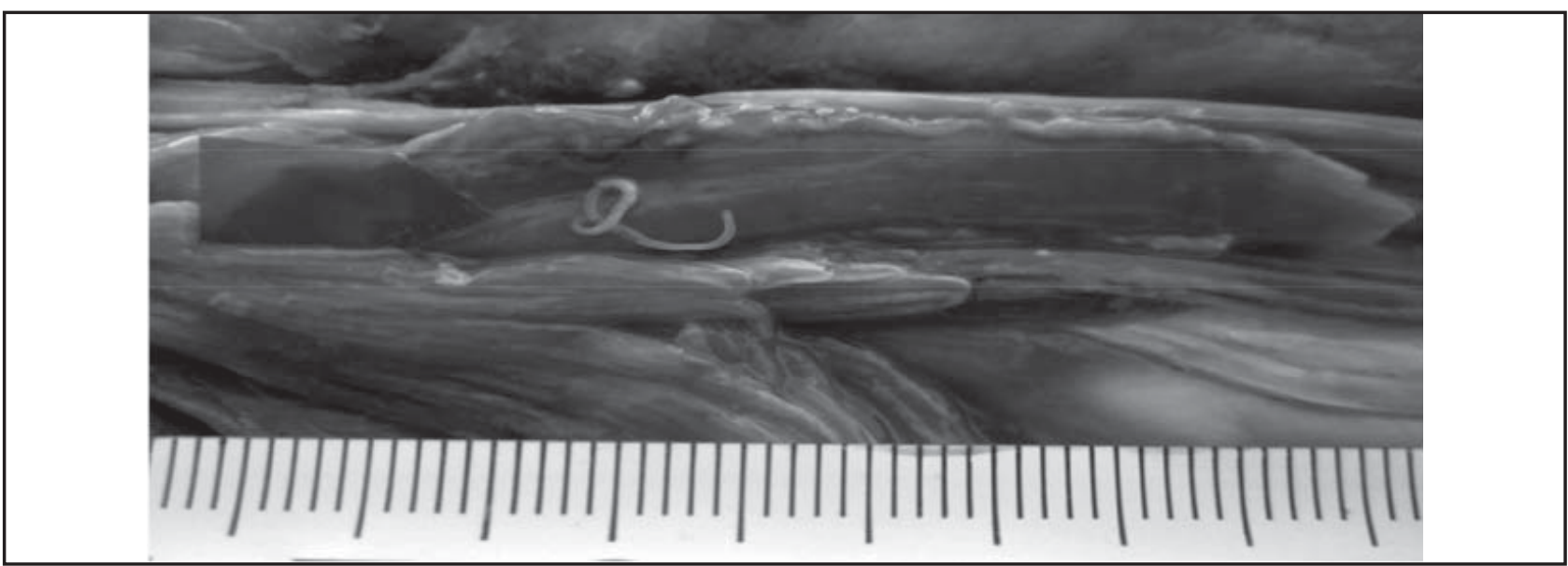

Figure1 The anisakid larvae cling in the abdominal cavity of S. jello.

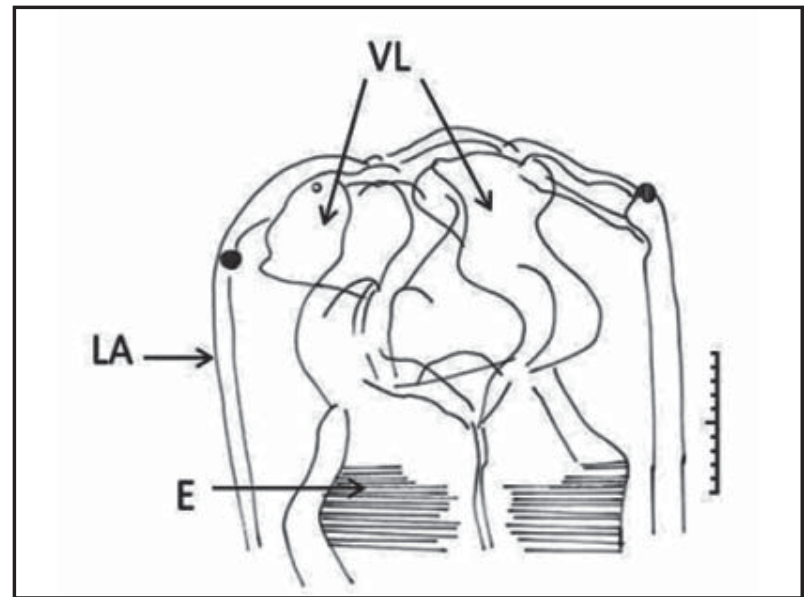

Figure 2 Anterior part of the body (E: Esophagus, VL: Ventrolateral Lips, LA: Lateral alae). Scale bar $=100 \mu \mathrm{m}$.

different gastrointestinal lesions (Kim, Choi, Lee \& Choi 2006). The nematodes that cause anisakiasis are larvae of Anisakis sp. in most cases followed by larvae of Pseudoterranova sp. Other anisakid lar- vae, such as Contracaecum sp. and Hysterothylacium sp. are hardly ever found in humans (Schaum \& Müller 1967; Ishikura 2003), however, Yagi, Nagasawa, Ishikura, Nagagawa, Sato, Kikuchi \& Ishikura (1996) reported a case of human infection with $\mathrm{H}$. aduncum in Japan and experimental reports of their hemorrhagic lesions were recorded in the rhesus monkeys stomach (Overstreet \& Meyer 1981). Although, some species do not have any record of causing disease in humans, their presence in the viscera and flesh may impact upon visual aesthetics and the market value, and parasite removal only adds to product cost while further reducing its attraction to consumers (Doupe' et al. 2003).

The third- stage of Hysterothylacium larvae have been infected some fish species of the Persian Gulf (Kardousha 1992; Petter \& Sey 1997; Al-Behbehani 2003; Bagherpour et al. 2011) whilst it is the 


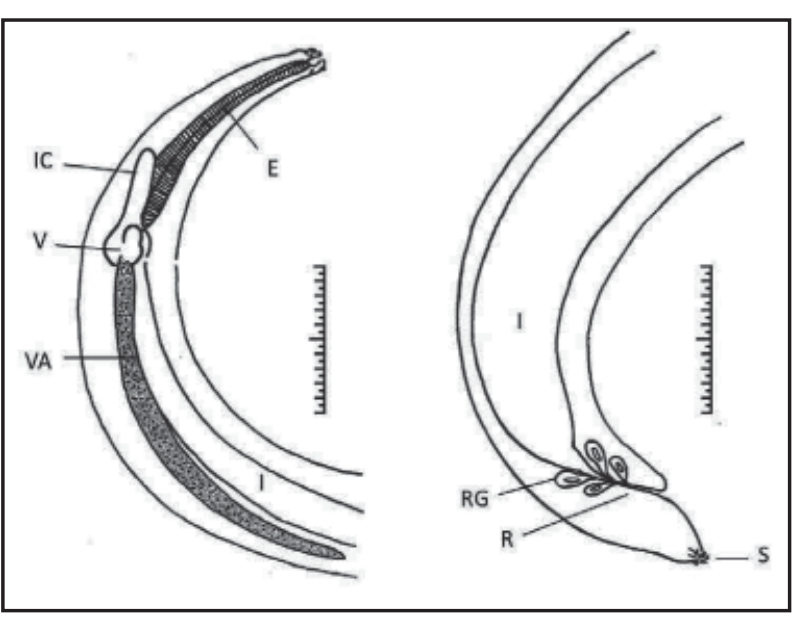

Figure 3 Hysterothylacium sp.; schematic drawing of anterior and posterior parts of the body (E: Esophagus, I: Intestine, IC: Intestinal Caecum, R: Rectum, RG: Rectal Glands, S: Spines, V: Ventriculus, VA: Ventricular Appendix). Scale bars $=1 \mathrm{~mm}$. Figure 4 The caudal multi-spinous of cactus-tail of four-stage larvae. Scale bar $=100 \mu \mathrm{m}$.

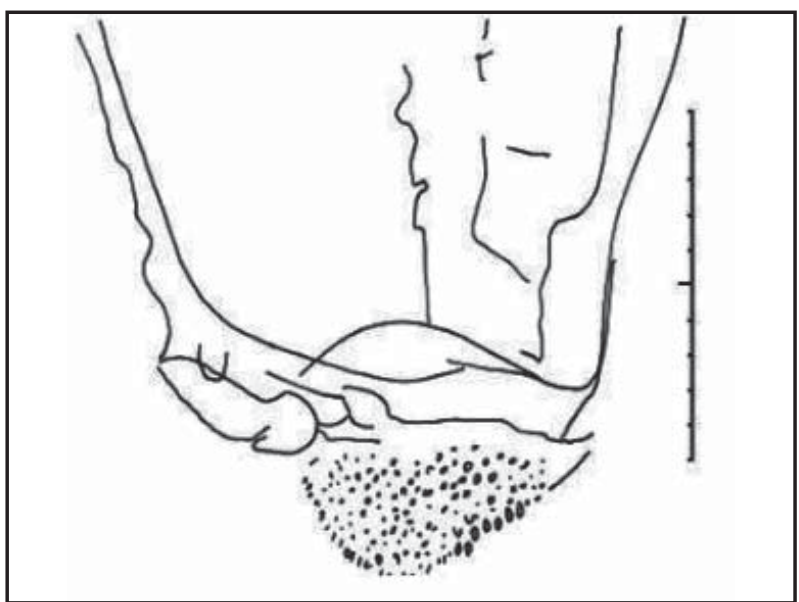

Figure 4 The caudal multi-spinous of cactus-tail of four-stage larvae. Scale bar $=100 \mu \mathrm{m}$.

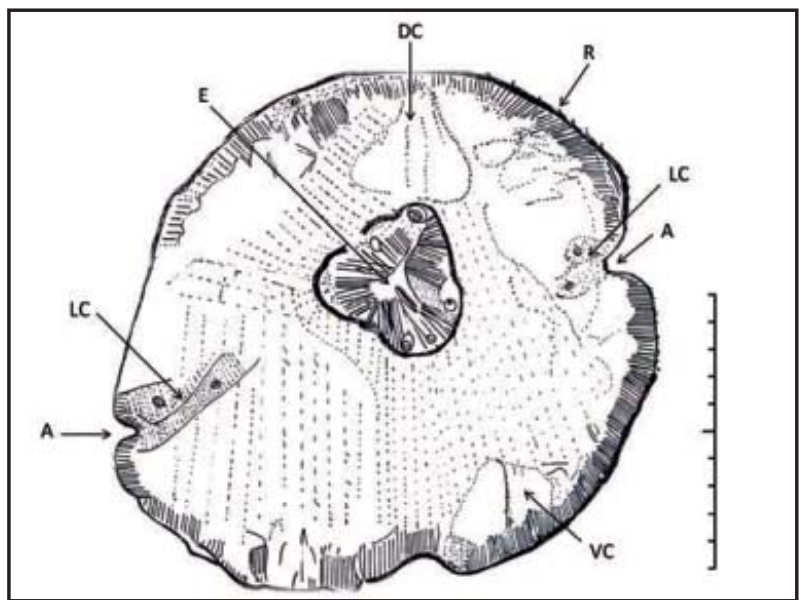

Figure 5 Hysterothylacium sp.; schematic drawing of cross section (A: Alae, E: Esophagus, DC: Dorsal cord, LC: Lateral cord, R: Ridges, VC: Ventral cord). Scale bar $=1 \mathrm{~mm}$. first record of the presence of its fourth- stage from the Persian Gulf fishes which appears that L4 stage larvae show a narrower host- specificity, however, more host species need to be investigated to support this proposal. Accordingly, presence of L3 and L4 stages of Hysterothylacium sp. in S. jello demonstrates that this fish can act as intermediate or definitive host for this parasite.

Third-stage larvae studied, differ from Hysterothylacium sp. type MB collected in S. jello by Kardousha (1992) in which a small boring tooth is present and tail ends with a terminal process.

Petter \& Sey (1997) classified Hysterothylacium larvae in six different types (KA-KF) and reported types KA and KB in S. jello. There are morphological similarities between the present specimens and type $\mathrm{KD}$ in having the arranged spines in the posterior extremity and ratio of esophagus length to ventricular appendix length (e/a) or intestinal caecum length $(\mathrm{e} / \mathrm{c})$. Comparing these features revealed that ventricular appendix was much longer than esophagus in the present specimens but their lengths were almost the same in type KA. In spite of the present types, ventricular appendix is shorter than twice the esophagus length and tail is tipped with a single terminal spine in type KB. So it can be concluded that the present type is different from types $\mathrm{KA}$ and $\mathrm{KB}$, previously described in S. jello.

According to other research conducted in Kuwaiti fishes by Al-Behbehani (2003) only one female of silver pomfret, Pampus argenteus was found infected (6.7\%) and the higher infection rate was recorded in malabar blood snapper, Lutjanus malabaricus in summer $(20.0 \%$ male and $22.2 \%$ female) and their third-stage larvae were similar to type KD of Petter \& Sey (1997). Bagherpour et al. (2011) reported H. aduncum in black sole fish, Brachirus orientalis from the Persian Gulf with the highest prevalence in spring $(56 \%)$, while in this study it occurred in summer thus further studies are required to assess its seasonal incidence. In the present study, larvae were only isolated from the abdominal cavity, although previously in some species were reported from the intestine and stomach of some fish (Lakshmi 1995 $a, b)$. The intensity of the infestation was correlat- 
ed with the size of the host in our study $(\mathrm{P}<0.05)$, Aloo, Anam \& Mwangi (2004) reported that large hosts can provide more appropriate habitats for parasites than small ones, on the other hand, as the fish grows, the amount of its food consumption increases, including the amount of larval stages consuming along.

The parasitation site of third stage larvae can confirm that studied fish acts as their paratenic hosts. In spite of the low infection rate of Hysterothylacium larvae, its occurrence might cause a serious public health problem. Therefore, consumption of infected fish if it is not properly cooked and ingestion of the immature worm may lead to anisakiasis. No human anisakiasis is yet reported from Iran, this issue could be attributed to cuisine habit of fish in studied areas as well as other parts of the country. The existence of Hysterothylacium larvae in S. jello in this region is of great concern for the health of these fish as hosts and human as consumers. Therefore, it increases the necessity to provide more information about ichthyoparasitoses and prophylactic approaches with the improvement of sanitary educational programs at various levels.

\section{Acknowledgements}

We wish to thank Mr. Abdy for their support during the work done at the University of Tehran (Iran). Financial support was provided by the University of Tehran and Iran Veterinary Organization.

\section{References}

Al-Behbehani B. (2003) Studies on Hysterothylacium sp. (Nematoda: Anisakidae) infecting Kuwaiti fishes. Egyptian Journal of Aquatic Biology and Fisheries 7(3), 279308.

Aloo P.A., Anam R.O. \& Mwangi J.N. (2004) Metazoan Parasites of Some Commercially Important Fish along the Kenyan Coast. Western Indian Ocean Journal of Marine Sciences 3(1), 71-78.

Anderson R.C. (2000) Nematode Parasites of Vertebrates, Their Development and Transmission, 2nd edn. CABI Publishing, London.
Bagherpour A., Afsharnasab M., Mobedi I., Jalali M. \& Mesbah M. (2011) Prevalence and intensity of internal parasitic helminthes infected Black sole fish, Brachirus orientalis (Bloch and Schneider, 1801) in the Persian Gulf. Iranian Journal of Fisheries Sciences 10(4), 570-584.

Brizzola S.M. \& Tanzola R.D. (1995) Hysterothylacium rhamdie sp. n., (Ascaridoidea: Anisakidae) from a Neotropical Catfish, Rhamdia sapo (Piscies: Pimelodidae). Memorias Do Instituto Oswaldo Cruz 90, 349-352.

Bush A.O., Lafferty K.D., Lotz J.M. \& Shostak A.W. (1997) Parasitology meets ecology on its own terms: Margolis et al. revisited. Journal of Parasitology 83, 575-583.

Carvajal J. \& Gonzales L. (1990) Presence of Hysterothylacium sp. (Nematoda: Anisakidae) in a cage-cultured coho salmon in Chile. Revista Chilena de Historia Natural 63, 165-168.

Deardorff T.L. \& Overstreet R.M. (1981a) Larval Hysterothylacium (=Thynnascaris) (Nematoda:Anisakidae) from fishes and invertebrates in the Gulf of Mexico. Proceedings of the Helminthological Society of Washington 48, 113-126.

Deardorff T.L. \& Overstreet R.M. (1981b) Review of Hysterothylacium and Iheringascaris (both previously = Thynnascaris) (Nematoda: Anisakidae) from the northern Gulf of Mexico. Proceedings of the Helminthological Society of Washington 93, 1035-1079.

Deardorff T.L. \& Overstreet R.M. (1982) Hysterothylacium pelagicum sp. n. and Hysterothylacium cornutum (Stossich, 1904) (Nematoda: Anisakidae) from Marine Fishes. Proceedings of the Helminthological Society of Washington 49, 246-251.

Doupe R.G., Lymbery A.J., Wong S. \& Hobbs R.P. (2003) Larval anisakid infections of some tropical fish species from north-west Australia. Journal of Helminthology 77, 363-365.

Felizardo N.N., Knoff M., Pinto R.M. \& Gomes D.C. (2009) Larval anisakid nematodes of the flounder, Para- 


\section{A Taheri Mirghaed et al., larval Hysterothylacium in pick handle barracuda}

lichthys isosceles Jordan, 1890 (Pisces: Teleostei) from

Brazil. Neotropical Helmintology 3(2), 57-64.

Gibbons L.M. (2010) Keys to the nematode parasites of vertebrates. Cambridge University Press.

Hoese D.F., Bray D.J., Paxton J.R. \& Allen G.R. (2006) Fishes. In: Zoological Catalogue of Australia (ed. by P.L. Beesley \& A. Wells.), pp. 1-2178. ABRS \& CSIRO Publishing.

Ishikura H. (2003) Anisakiasis (2) Clinical pathology and epidemiology. In: Progress of Medical Parasitology in Japan (ed. by S. Otsuru, S. Kamegai and S. Hayashi), pp. 451-473. Meguro parasitological museum, Tokyo.

Kardousha M.M. (1992) Helminth parasite larvae collected from Arabian Gulf fish (Coasts of the United Arab Emirates). (I) Anisakid larvae (Nematoda: Anisakidae). Japanese Journal of Parasitology 41(6), 464-472.

Kim Y.H., Choi W.B., Lee S.C. \& Choi H.W. (2006) Three cases of Colonic Anisakiasis. Korean Journal of Gastrointestinal Endoscopy 33, 239-243.

Køie M. (1993) Aspects of the life-cycle and morphology of Hysterothylacium aduncum (Rudolphi, 1802) (Nematoda, Ascaridoidea, Anisakidae). Canadian Journal of Zoology 71, 1289-1296.

Lakshmi R.I. (1995a) Hysterothylacium channai n. sp. (Nematoda: Anisakidae) from the intestine of Channa punctatus Bloch from Kolleru lake (Andhra Pradesh). Rivista di Parassitologia 12, 221-228.

Lakshmi R.I. (1995b) Hysterothylacium punctati sp. nov. (Nematoda: Anisakidae) from the stomach of the fresh-water fish, Channa punctatus Bloch. Geobios New Report 14, 123-129.

Moravec F. \& Nagasawa K. (1998) Hysterothylacium japonicum sp. n. (Nematoda: Anisakidae) from the rare marine fish Trachipterus ishikawai in Japan. Acta Parasitology 43, 39-42.
Nagasawa K. (2005) Anisakiasis. In: Marine Parasitology (ed. by K. Rohde), pp. 430-434. CSIRO Publishing, Australia.

Overstreet R.M. \& Meyer G.W. (1981) Hemorrhagic lesions in stomach of rhesus monkey caused by a piscine ascaridoid nematode. Journal of Parasitology 67, 226-235.

Petter A.J. \& Sey O. (1997) Nematode parasites of marine fishes from Kuwait, with a description of Cucullanus trachinoti n. sp. from Trachinotus blochi. Zoosystema 19, $35-59$.

Randall J.E., Allen G.R. \& Steene R.C. (1997) Fishes of the Great Barrier Reef and Coral Sea. Crawford House Press, Bathurst, Australia.

Schaum E. \& Müller W. (1967) Die Heterocheilidiasis. Eine Infection des Menschen mit Larven Von Fisch-Ascariden. Deutsche Medizinishe Wochenschrift 92, 22302233 (In German).

Yagi K., Nagasawa K., Ishikura H., Nagagawa A., Sato N., Kikuchi K. \& Ishikura K. (1996) Female worm Hysterothylacium aduncum excreted from human: a case report. Journal of Parasitology 45, 12-23. 


\section{ثبت جديد لارو انكل هيستروتيلاسيوم از نماتودهاى رافيدآسكاريديده در ماهى كوتز

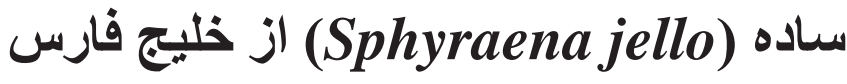

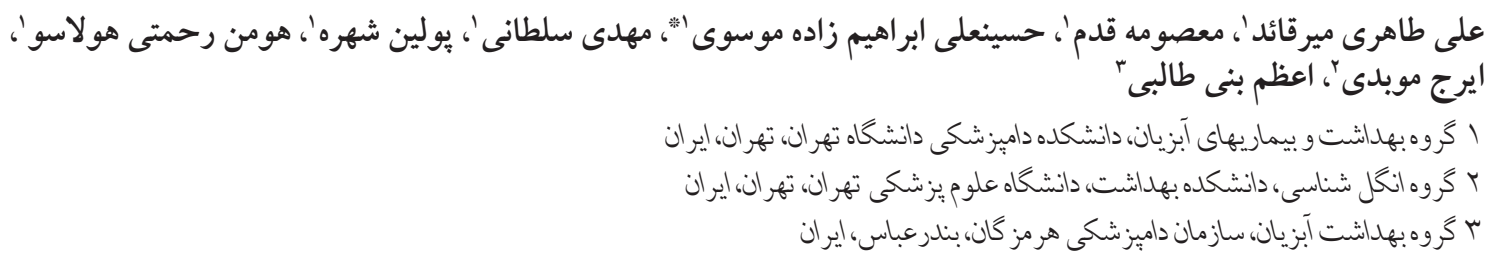

ماهى كوتر ساده يكى از مهمترين گونههاى تجارى خليج فارس مىباشد. به منظور شناسايى آلودگى به نماتودها ، تعداد • صا عدد كوتر از سه سايت

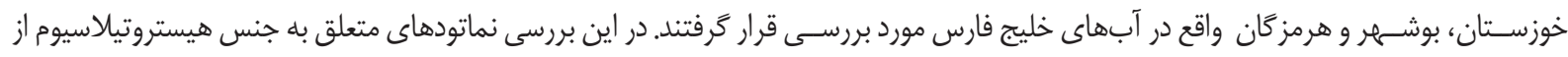

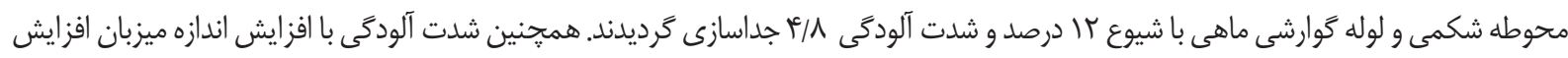

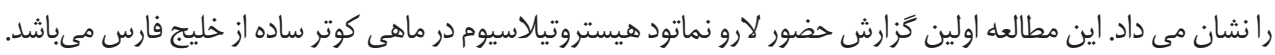

وازههاى كليدى : هيستروتيلاسيوم، كوتر ساده، نماتود، خليج فارس. hmosavi@ut.ac.ir : 